\title{
KEGAGALAN PERANG DINGIN \\ ANTARDUA NEGARA ADIDAYA: FAKTOR PENYEBAB DAN IMPLIKASINYA
}

\author{
Oleh: Murtamadji \\ (Dosen FIP / MKU -UNY)
}

\begin{abstract}
Abstrak
Kajian ini bertujuan untuk mencoba mengungkap beberapa faktor penyebab gagalnya perang besar antara Amerika Serikat dengan Uni Soviet yang boleh kita sebut sebagai Perang Dunia III di era Perang Dingin. Setelah berakhirnya PD II Amerika Serikat dan Uni Soviet dianggap sebagai dua negara adidaya yang memiliki kekuatan yang terkuat di dunia. Keduanya saling bersaing dan berusaha memperluas pengaruhnya terhadap negara-negara di dunia. Dari persaingan, pergolakan, dan ketegangan serta kecurigaan ini terjadilah konflik antara kedua negara Adidaya tersebut yang disebut Perang Dingin. Hingga pecahnya negara Uni Soviet Perang Dingin ini tidak kunjung terjadi.

Kajian ini apat dijadikan pelajaran bagi negara-negara lain, terutama negara yang sedang berkembang untuk tidak menggantungkan diri pada negara besar dalam mencari perlindungan keamanan, agar tidak dijadikan alat untuk kepentingan promosi kekuatan senjata oleh negara super power. Justeru dengan mengembangkan kekuatan militer secara profesional yang dibarengi dengan pengembangan IPTEK dan persenjataan yang canggih, akan mampu mengimbangi kekuatan negara lawan, sehingga hal ini dapat berfungsi sebagai daya tangkal bagi negara lawan. Dari sinilah kita bisa mencermati jargon "Sivis Pakem Para Bellum”, artinya "jika Anda ingin damai maka bersiaplah untuk perang”.
\end{abstract}

\section{Pendahuluan.}

Alinea I dari preambul Piagam Perserikatan Bangsa Bangsa menonjolkan tekat rakyat untuk mengikis habis laknat derita yang ditimbulkan oleh perang. Alinea itu berbunyi, "We the peoples of the United Nations determined to save succeeding generationsfrom the scourge of war, which twice in our lifetime has brough unlold sorrow to mankind, and ...". Artinya, kami rakyat dari Persatuan Bangsa 
Bangsa bertekat untuk menyelamatkan generasi-generasi penerus dari laknat penderitaan perang yang dua kali dalam kehidupan kami telah menimbulkan penderitaan tak terkata terhadap kemanusiaan, dan...(A. Hasnan Habib, dalam Jurnal Ketahanan Nasional, 1997: 35).

Dari piagam tersebut dapat diketahui bahwa keinginan manusia untuk menciptakan bumi tempat hidupnya menjadi suatu dunia yang damai, aman, tenteram, dan sejahtera bukanlah yang pertama kali didengungkan pada akhir Perang Dunia II. Sebenarnya hal itu merupakan keinginan dari sebagian besar umat manusia di dunia sejak dahulu kala. Namun, kenyataan perang masih banyak terjadi di belahan bumi ini.

Perserikatan Bangsa Bangsa (United Nation Oranization) menetapkan tahun 1986 sebagai tahun perdamaian, dengan harapan pada tahun tahun selanjutnya usaha-usaha ke arah perdamaian dapat lebih meningkat lagi. PBB (UNO) didirikan untuk menyalurkan harapan rakyat sedunia, yaitu terwujudnya perdamaian setelah Perang Dunia Kedua yang telah banyak menelan korban. PBB memang berhasil mencegah terjadinya PD III yang didukung oleh adanya kekuatiran dari negara-negara adidaya itu sendiri akan akibat dari perbuatannya, meskipun selama itu telah terjadi perang lokal di manamana yang meminta korban jiwa yang lebih banyak jika dibanding saat Perang Dunia II. Selain itu, sejak tahun 1945 perkembangan persenjataan meningkat terus baik dari segi kuantitas maupun kualitasnya, misalnya hulu ledak dan daya jangkau serta ketepatan sasaran yang tidak diragukan lagi dari senjata tersebut, telah menjadi ancaman terhadap perdamaian dunia.

Timbunan senjata nuklir yang ada yang cukup untuk membunuh setiap orang sampai 12 kali jumlah penduduk dunia saat ini. Yang lebih mengerikan lagi, senjata nuklir daya pemusnahnya cukup memakan waktu yang panjang sampai pada generasi turun temurun. Hal ini seperti yang dituturkan oleh T. Yacob (1993: 119) sebagai berikut :

"Akibat perang nuklir tidak terbayangkan luas dan kejamnya. Akibat terburuk adalah kepunahan manusia, rusaknya ekosistem manusia, dan terganggunya biosfir dan stratosfir secara global. Akibat yang segera timbul adalah kematian massal karena ledakan panas dan radiasi, yang diperhebat pula oleh runtuhnya bangunan, kebakaran sekunder, rusaknya sistem penunjang, seperti listrik, komunikasi, pengangkutan, serta terjadinya kontaminasi sumber air dan makanan. Sedang yang tidak mati akan menderita penyakit radiasi, luka bakar, patah tulang, 
perdarahan, infeksi sekunder dan shocks psikhologis. Selain itu yang masih hidup juga akan menghadapi bahaya-bahaya berikut ini seumur hidupnya antara lain leukimia, tumor ganas, katarak radiasi, efek genetis, yang menurunkan kelainan pada generasi penerus berikutnya. Korban dalam jumlah manusia lebih banyak. Perang nuklir antara Amerika dan Uni Soviet dalam dasa warsa ini diramalkan akan mengakibatkan 200 juta manusia mati seketika dan 60 juta terluka, 30 juta lainnya akan menderita penyakit radiasi, 20 juta menderita trauma dan luka bakar, sedangkan yang 10 juta lagi menderita baik trauma, luka bakar maupun penyakit radiasi."

Setelah selesainya PD II Amerika Serikat dan Uni Soviet dianggap sebagai dua negara super power yang jauh lebih kuat dari negara-negara lain di dunia. Kedua negara adidaya ini saling bersaing satu dengan yang lain dan masing-masing berusaha memperluas pengaruhnya terhadap negara-negara di dunia. Amerika Serikat adalah negara yang menganut paham kapitalis dan Uni Soviet sebagai negara yang menganut paham sosialis komunis. Taksatupun dari keduanya yang cukup kuat untuk memaksakan keinginannya yang satu kepada yang lainnya.

Selanjutnya jika dilihat dari kekuatan militer dan persenjataan, mereka juga saling bersaing satu sama lain. Amerika Serikat menekankan pada kualitas persenjataan dan personil militernya, sedang Uni Soviet dari segi kuantitas persenjataan yang dimiliki. Dari persaingan ini maka timbullah ketegangan antara Amerika Serikat dan Unisoviet yang dilandasi adanya kecurigaan di antara kedua negara adidaya tersebut. Dari persaingan, pergolakan, dan kecurigaan serta ketegangan ini terjadilah posisi konflik antara kedua negara adidaya tersebut yang disebut Perang Dingin.

Pengaruh dua negra adidaya itu melibatkan negara-negara kecil yang bukan negara super power. Hal ini terjadi karena negara-negara kecil tersebut berkecenderungan mencari perlindungan keamanan dari negara-negara yang mereka anggap kuat dan mampu melindungi serta punya pengaruh. Kondisi itulah yang justeru memicu terjadinya konflik-konflik regional di kalangan negara-negara kecil yang sedang berkembang. Konflik-konflik regional ini memsnh tidak terlepas dari pengaruh ketergantungan negara-negara kecil terhadap negara-negara super power tersebut.

Dari uraian tersebut di atas maka dapat diketahui bahwa Amerika Serikat dan Uni Soviet sebagai dua negara adidaya 
mempunyai andil terjadinya konflik regional di belahan bumi ini. Atas dasar itulah maka dapat dikemukakan satu masalah, mengapa Perang Dunia Ketiga tidak terjadi selama Perang Dingin dan perlombaan senjata di kedua belah pihak berlangsung, serta masing masing pihak terlibat dalam berbagai konflik regional di belahan bumi ini?

\section{Hakikat Perang dan Perang Dingin}

Menurut Jenderal Clausewitz perang adalah suatu kelanjutan dari politik dengan "cara cara lain" sejak lama di masa lalu. Yang dimaksud dengan "cara cara lain" di sini adalah digunakannya kekuatan senjata. Dengan demikian, hakikat perang menurut Clausewitz adalah pertarungan antara dua kekuatan yang saling bertentangan dengan menggunakan kekerasan senjata. Yang dimaksud dengan kekerasan senjata ialah menonjolnya peranan angkatan bersenjata sebagai sarana untuk menyelesaikan persengketaan tanpa mengecilkan arti peranan kekuatan-kekuatan yang lain, seperti kekuatan politik, ekonomi, psikologis, dan lain sebagainya (Lemhannas, 1988: 218).

Perang sudah ada dan dikenal sejak manusia ada dan tetap ada sepanjang manusia ada. Oleh sebab itu, perang tidak dapat dielakan oleh manusia, karena sudah pembawaan biologisnya yang telah melekat sejak lahir, sehingga watak manusia cenderung agresif. Jelasnya, untuk selalu mendominasi pihak lain, manusia menyalurkannya dengan perang (Amin Rais, 1989: 21). Atas dasar itulah maka ada orang yang merasa heran karena ada orang yang memperjuangkan perdamaian dan menyangka bahwa perang dunia tidak akan terjadi setelah sekian lama, dan manusia merasa kehilangan sumber ketegangan yang mengasyikkan, pemuasan jiwa dalam keyakinannya harus diganti dengan cara-cara lain, dan perang itu dianggap sebagai takdir untuk menyaring bangsa yang unggul.

Perang juga mempunyai peranan yang positif, karena dapat menentukan atau setidaknya memengaruhi sejarah peradaban manusia, yaitu terjadinya akulturasi antarbudaya bangsa, atau terhapusnya kebudayaan lama untuk kemudian digantikan dengan kebudayaan yang baru. Di samping itu dapat terjadi pengembangan dan penerapan IPTEK yang bermanfaat bagi kehidupan umat manusia di masa damai.

Perang dewasa ini tidak hanya merupakan persoalan bagi pimpinan dan ahli-ahli perang saja, tetapi sudah menjadi persoalan 
seluruh rakyat, bahkan juga menyangkut peri kehidupan seluruh umat manusia di bumi. Hal ini karena beberapa hal:

1. Perubahan dalam sistem nilai dan persepsi mengenai moral;

2. Perkembangan teknologi perang dengan ditemukannya senjata mutakhir dengan daya pemusnah yang dahsyat dan berakibat tidak dapat dibangunnya kembali daerah yang terkena radiasi dan kontaminasi nuklir dalam jangka waktu yang relatif singkat;

3. Perkembangan Ilmu Pengetahuan dan Teknologi di bidang komunikasi yang pesat mempererat hubungan antarbangsa tanpa batas di bidang politik, ekonomi, sosial, dan budaya dalam usaha meningkatkan kesejahteraan umat manusia; dan

4. Tumbuhnya kesadaran nasional dan demokrasi yang secara umum dapat dikatakan bahwa apapun alasannya setiap bangsa melakukan perang untuk memaksakan kehendaknya atau memperluas daerah pengaruhnya dalam rangka mewujudkan cita-cita nasionalnya.

Sivis Pakem Para Bellum merupakan ungkapan Yunani kuno yang mengandung paradox "Jika Anda ingin damai, maka bersiaplah untuk berperang“. Oleh sebab itu, suatu negara yang hanya memperhatikan kesejahteraan saja dan mengabaikan masalah pertahanan dan keamanan nasionalnya, maka negara tersebut mudah ditekan atau ditaklukkan oleh bangsa lain yang sudah siap untuk berperang. Dalam hal ini kesiapan untuk berperang mutlak diperlukan bagi setiap negara, karena dapat merupakan faktor pencegah terhadap usaha perang lawan (deteren faktor) (Morgenthau, 1992: 7).

Dalam meninjau spektrum perang dapat diketahui ada berbagai bentuk perang yang meliputi perang umum, perang terbatas, perang revolusioner, dan perang dingin. Meskipun dalam spektrum perang kita mengenal berbagai bentuk perang, namun dalam tulisan ini yang akan dikaji hanya Perang Dingin antara dua negara adidaya, yaitu Amerika Serikat dan Uni Soviet.

Perang Dingin adalah suatu bentuk perang yang pada umumnya tidak menggunakan kekuatan angkatan bersenjata secara langsung, tetapi menggunakan cara-cara, alat-alat, dan kekuatan-kekuatan ideologi, politik ekonomi, sosial budaya, dan alat-alat lain yang serupa dengan itu guna mencapai tujuan nasional. Walaupun ciri dasar dari Perang Dingin adalah tidak terdapatnya persengketaan bersenjata, namun peranan militer sangat penting dalam Perang Dingin, karena angkatan bersenjata yang kuat dapat digunakan untuk mengancam maupun menekan lawan baik langsung maupun tidak langsung. 
Perang Dingin memang muncul setelah Perang Dunia II yang mempunyai arti bahwa di dalam konteks hubungan internasional yang ada terjadi struggle for power besar-besaran melalui konflik-konflik politik, ideologi antara dua blok yang berlawanan, yaitu blok kapitalis liberal yang dipimpin oleh Amerika Serikat dan blok sosialis komunis yang dipimpin oleh Uni Soviet. Di dalam Perang Dingin sarana apapun digunakan untuk menambah power dan pengaruh sendiri serta guna membendung power dan dominasi lawan. Cara ini bukanlah gejala baru, karena di masa lalu negara-negara telah berusaha membendung power lawan mereka dengan menerapkan berbagai cara dan sarana selain perang (Morgenthau, 1993: 3). Hal yang baru dalam Perang Dingin yang dimulai setelah Perang Dunia II menjadi nyata bahwa masalah tersebut tersebar dan meluas ke seluruh dunia, dalam arti bahwa tidak ada bagian dari dunia ini yang tidak terlibat dalam scope-nya. Sebenarnya akar dari Perang Dingin adalah ambisi dari masing-masing negara adidaya yang tidak cocok dan ideologi mereka yang bertentangan. Di satu sisi tujuan Uni Soviet sesudah perang adalah dapat menjamin keamanan nasionalnya terhadap kemungkinan agresi dari lawan-lawannya dan modifikasi status quo internasional dengan penyebaran ideologi komunis yang cepat. Sedang Amerika Serikat sebagai super power, sebagaimana pemimpin kekuatan kekuatan status quo, berusaha membendung Rusia melalui intervensinya di negara-negara lain, pembentukan aliansi militer dan dengan menggunakan berbagai cara dan tindakan anti komunis (Containment Policy).

Perang dingin menjadi bentuk perjuangan Timur dan Barat atau sebagai perjuangan antara camp sosialis dan imperalis. Struktur bipolar sesuai perang ini juga merupakan sebab dari Perang Dingin, jika super power dalam berhadapan satu sama lain secara positif mengetahui hanya lawannya yang dapat menjadi musuh berbahayanya. Maka dalam situasi demikian itu sangat diperlukan adanya diplomasi yang handal. Penggunaan kekerasan dengan dasar apapun, selain perang total, sebenarnya tidak mungkin, karena tidak satu pun blok yang ingin tunduk pada demonstrasi kekuatan atau ancaman belaka, sehingga jalan buntu yang akan ditemui.

Dalam masa Perang Dingin persyaratan nuklir dapat bertindak sebagai pencegah. Dalam politik deteren (pencegahan), senjata nuklir telah berfungsi sebagai back ground umum untuk negoisasi dari posisi yang kuat. Hal ini merupakan ajaran yang baik yang memerlukan perhatian yang seksama, karena instrumen memang benar-benar 
memberikan dukungan dan jaminan stabilitas. Karena itu, selama Perang Dingin kedua belah pihak mengambil sikap dingin.

Perang Dingin tidak didasarkan semata-mata pada balance of power (perimbangan kekuatan) tetapi juga pada keseimbangan ancaman (balance of teror), sehingga kemungkinan terjadinya perang fisik yang terbuka juga kecil, apalagi perang nuklir. Hal ini dianggap sebagai resiko bunuh diri dan menuntut adanya korban yang terlalu besar bila mendahului melakukan penyerangan. Atas dasar itulah maka keseimbangan ancaman yang tersebab adanya keseimbangan kekuatan dalam era nuklir tersebut sangat cocok bagi hubungan internasional antara negara-negara super power dengan persenjataan nuklir yang dimilikinya. Dengan demikian, syarat dan wujud hubungan internasional menghasilkan sebuah politik pemeliharaan garis dan mewujudkan ketegangan yang bertindak sebagai deteren. deteren tidak hanya merupakan teknik militer namun juga merupakan konsep diplomasi yang dibutuhkan guna menghambat musuh yaitu yang menyebabkan suatu agresi tidak melakukan suatu tindakan. Dengan demikian, deteren dapat dianggap sebagai konsep psikologis, karena konsep ini menggunakan ancaman untuk memengaruhi suatu maksud lawan.

Masa Perang Dingin bukanlah perang dalam arti tradisional, tetapi juga bukan merupakan damai dalam arti tidak ada perang. Meskipun perdamaian umum ada, perang terbatas sering terjadi di beberapa bagian bumi yang berbeda. Kedua negara adidaya menahan diri mereka untuk tidak terlibat secara langsung dalam berbagai konflik melainkan hanya diwakili oleh sekutu-sekutu mereka. Mereka mempersenjatai sekutu-sekutu mereka untuk dijadikan alat-alat besinya secara terbuka, dan untuk meyakinkan lawan mereka mengenai kemampuan yang dimiliki untuk menyerang secara menentukan. Hubungan bermusuhan ditonjolkan, tetapi tidak sampai pengesampingan negosiasi dan penggunaan kekerasan yang terbatas. Perang Dingin merupakan masalah serius bagi hubungan internasional. Adapun masalah tersebut berupa ideologi dan kedaulatan suatu negara berkurang fungsinya. Ketergantungan keamanan dari negara-negara kecil terhadap negara-negara super power menuntut pelibatan negara-negara super power dalam mewakili kedua kubu yang bermusuhan dan menggunakan diplomasi agar tidak terjadi konflik perang secara langsung.

Perang Dingin mempunyai konsekuensi kemacetan militer yang merupakan akibat langsung sikap hati-hati negara-negara super power yang menganggap lawan mempunyai persenjataan nuklir baik dari 
segi kualitas maupun kuantitas yang cukup untuk melancarkan serangan yang menentukan. Perang tersebut dapat menimbulkan kehancuran kedua belah pihak dan mengorbankan jutaan penduduk dunia, sehingga perang dunia ketiga dapat dihindarkan. Dan kenyataannya kedua pihak negara super power saling mempertahankan kekuatannya, sehingga Perang Dingin tidak pecah menjadi Perang Dunia Ketiga, dan hanya menyebabkan dunia cemas, tegang, tidak tenang lantaran kematian yang tertunda. Hal tersebut terjadi berkat negara super power saling mengimbangi kekuatan, membandingkan kekuatan, mengurangi persenjataan, serta peran aktif dari Perserikatan Bangsa Bangsa, perang antara Amerika Serikat dengan Uni Soviet secara terbuka atau perang dengan menggunakan senjata nuklir tidak terjadi sampai berakhirnya Perang Dingin.

\section{Organisasi Regional dan Konflik Regional.}

Untuk menjawab masalah mengapa tidak terjadi perang besar antara Amerika Serikat dengan Uni Soviet (Yang dapat disebut sebagai Perang Dunia III), sedangkan konflik dan perang regional di berbagai belahan dunia terjadi, terlebih dahulu akan dibahas konflik regional yang terjadi di berbagai belahan dunia. Dengan berakhirnya Perang Dingin tidak menjadikan dunia lebih stabil, aman, dan tertib. Adapun yang hilang untuk sementara adalah ancaman perang nuklir antara Amerika Serikat dengan Uni Soviet. Namun, kenyataan menunjukkan pada kita bahwa berbagai negara masih ada yang tidak bersedia menghentikan percobaan nuklir dan senjata pemusnah massal lainnya. Sedangkan pengadaan senjata komersial masih tetap berkembang terus baik dalam kuantitas maupun kualitasnya di negaranegara berkembang.

Dengan ambruknya Uni Soviet yang merupakan salah satu negara super power, Amerika Serikat menjadi satu-satunya penguasa dunia. Sebagai akibatnya di negara-negara sedang berkembang terjadi keadaan ketidakstabilan. Hal ini ditandai oleh adanya persaingan antarbangsa-bangsa, misalnya sengketa antar etnik, intoleransi agama, rasialisme, ekstremisme, kecaman politik dan ekonomi di berbagai wilayah, perkembangan senjata di berbagai negara berkembang semakin meluas, hubungan Utara Selatan tidak stabil, pecahnya negara-negara seperti Uni Soviet, bekas Yugoslavia, dan bersatunya kembali Jerman Barat dan Jerman Timur serta gejalanya dibagian negara Afrika, dan lain-lainnya. 
Peristiwa-peristiwa di atas takdapat dikatakan sebagai Perang Dunia III, tetapi hanya merupakan konflik regional, karena tidak melibatkan banyak negara besar secara langsung. Artinya, hanya negara-negara kecil yang menjadi sekutu dari Amerika Serikat dan Uni Soviet saja yang melakukan konflik.

Selanjutnya dalam tulisan ini akan dibahas mengenai peran organisasi-organisasi regional dan aliansi dalam era perdamaian dunia. Organisasi tersebut adalah North Atlantic Treaty Organization (NATO) dan Pakta Warsawa. Kedua organisasi tersebut berorientasi pada pertahanan dan keamanan regional yang paling terkenal di antara organisasi regional yang lain yang juga sebagai pakta misalnya South East Asia Treaty Organization (SEATO). Organisasi ini telah bubar. Yang masih ada misalnya Liga Arab, ASEAN (Association of South East Asian Nation), Anzus (Australia, New Zeland, dan Amerika Serikat), dan organisasi regional lainnya.

Dalam arena politik internasional organisasi yang terbentuk di atas berasumsi bahwa dengan pembentukan kerjasama pertahanan keamanan regional dan pembentukan organisasi politik, ekonomi regional, dan lain lain, serta negara-negara yang merasa senasib sepenanggungan dalam satu wilayah regional maupun banyak kemiripan tradisi dan budaya bersamaan kepentingan, bisa diharapkan organisasi kerjasama pada tingkat regional akan punya prospek yang lebih cerah untuk menangani masalah perang dan damai secara politis. Hal ini bisa menjadi dasar bagi argumen bahwa regionalisme dapat merupakan sarana mencapai perdamaian dunia. Organisasi ini memang dibenarkan oleh PBB yaitu menurut pasal 52 s/d 54 yang mengatur persetujuan regional. Walaupun demikian, ada perbedaan pendapat dalam hal pembentukan organisasi tersebut, seperti misalnya NATO, berdasarkan pasal 52 piagam PBB untuk menjamin keamanan kolektif, tetapi ternyata tidak demikian. Organisasi itu dibenarkan karena adanya sistem aliansi regional yang dirancang untuk meningkatkan pertahanan diri secara kolektif dalam menghadapi musuh dari luar secara bersama-sama.

Dengan maksud baik secara global maupun regional semua anggota saling menjamin satu sama lain. Siapa yang mengganggu keamanan akan dihadapi bersama-sama. Hal ini merupakan hubungan dari aliansi perdamaian dunia secara global. Tetapi dalam kenyataannya konflik yang terjadi juga karena adanya keterlibatan pengaruh dari dua negara adidaya, yakni Amerika Serikat dan Uni Soviet, meskipun secara tidak terang-terangan. Konflik regional tersebut memang sengaja diciptakan untuk kepentingan promosi 
kekuatan senjata, sehingga negara-negara yang mempunyai ketergantungan perlindungan keamanan saling berlomba untuk membeli senjata, menyusun kekuatan, serta mengembangkan kekuatan, sebagai langkah untuk berjaga-jaga dari ancaman agresi negara lain. Agar tidak terjadi konflik maka perlu pendekatan "perimbangan kekuatan". Hal ini didasarkan pada asumsi bahwa pendistribusian kekuatan melalui dinamika politik persekutuan akan menghasilkan perdamaian. Perimbangan kekuatan merupakan serangkaian aturan untuk mengurangi frekuensi perang dan bertujuan untuk mengakhiri perang serta untuk mencegah peningkatan kekuatan satu negara atau sekelompok negara secara besar besaran. Dengan demikian, perimbangan kekuatan itu memang penting di dalam menjamin perdamaian dunia.

\section{Kesimpulan}

Berdasarkan uraian di atas maka dapat dikemukakan kesimpulan sebagai berikut:

1. Perang Dunia III tidak terjadi meskipun ditandai dengan adanya Perang Dingin yang melibatkan Amerika Serikat dan Uni Soviet sebagai negara super power, karena adanya balance of power dan balance of teror dari kedua negara super power tersebut, sehingga sama-sama takut untuk mendahului. Sebab lain adalah adanya ambisi dari kedua negara super power untuk mempertahankan status quo yakni Uni Soviet dengan penyebaran ideologi komunis, dan Amerika Serikat dengan status quo-nya sebagai pemimpin dunia yang berusaha membendung Uni Soviet (Rusia) melalui intervensinya ke negara-negara lain.

2. Perang Dingin melibatkan senjata nuklir. Oleh sebab itu, senjata nuklir sangatlah efektif untuk berjaga-jaga, sehingga menyebabkan tidak terjadi perang fisik yang terbuka antara Amerika Serikat dengan Uni Soviet. Kedua negara adidaya memiliki persenjataan pemusnah massal (nuklir) dan persenjataan konfensional yang seimbang, baik secara kuantitas maupun kualitas. Amerika Serikat mengutamakan segi kualitas persenjataan sedangkan Uni Soviet mengutamakan segi kuantitas persenjataannya.

3. Adanya perimbangan persenjataan nuklir dan sikap moral yang baik pada kedua negara adidaya tersebut justeru menyebabkan timbulnya sikap hati-hati kedua negara adidaya dalam mengambil 
keputusan untuk menekan tombol nuklir. Sikap hati-hati dan sama-sama takut untuk mendahului ini menyebabkan Perang Dunia III tidak jadi pecah, meskipun di belahan bumi yang lain terjadi berbagai konflik regional.

\section{Daftar Pustaka}

Iclasul Amal \& Armaidy Armawi. (1997). Sumbangan Ilmu Sosial Terhadap Konsepsi Ketahanan Nasional. Yogyakarta: Gadjah Mada Press.

Jurnal Ketahanan Nasional, Vol. II No. 1, April 1997, Kerjasama Prodi Ketahanan Nasional PPS UGM Yogyakarta dengan Lemhannas Jakarta.

Lemhanas. (1988). Kewiraan untuk Mahasiswa. Jakarta: Penerbit Depdikbud dan Lemhannas.

Morgenthau, Hans J. (1992). Politik Antar Bangsa. Jakarta: Yayasan Obor Indonesia.

(1993). Teori Realisme Politik Internasional (Suatu Analisis Kritis). Surakarta: UNS Press.

Rais, M. Amin. (1989). Politik Internasional Dewasa Ini. Surabaya: Penerbit Usaha Nasional.

T. Jacob. (1993). Manusia Ilmu Dan Teknologi. Yogyakarta: Tiara Wacana. 


\section{Biodata Penulis}

Murtamadji, M.Si. lahir di Yogyakarta, 8 Februari 1954, lulus Fisipol Sosiologi UGM 1983, dan lulus Magister (S-2) Ketahanan Nasional di UGM Yogyakarta pada tahun 2001. Mulai bekerja di IKIP Yogyakarta (UNY sekarang) tahun 1986 di Jurusan MKU FPIPS. Sekarang menjadi dosen di FSP FIP UNY. Salah satu karya ilmiah dengan judul Konflik dan Tindak Kekerasan Serta Upaya Menumbuhkan Integrasi di Indonesia dimuat dalam majalah Informasi Fakultas Ilmu Sosial UNY (2001). 